\title{
Evaluation of Finnish apple cultivars (Malus domestica Borkh.)
}

\author{
Nina Krasova, Zoya Ozherelieva and Anna Galasheva \\ Laboratory of apple cultivars investigation and agronomic practice, \\ Russian Research Institute of Fruit Crop Breeding (VNIISPK), 302530, Zhilina, Orel region, Russia \\ e-mail: krasovang@vniispk.ru
}

\begin{abstract}
The purpose of this research was to study apple cultivars obtained from Luke (previously MTT Piikkiö, Finland) in order to have good candidates for breeding within the central zone of Russia. The studies were carried out in accordance with the methods of cultivar study and artificial freezing by modeling damaging factors using a freezing chamber. The assessment of the cultivars by yield, commodity and consumer qualities of fruit, resistance to adverse abiotic factors of the winter period is given. The 'Vuokko' cultivar was identified with a yield significantly higher than Antonovka. By modeling winter damage factors, 'Sandra', 'Samo' and 'Make' cultivars were identified with the resistance of the cambium and wood at the level of 'Antonovka', when the temperature in the of mid-winter dropped to $-40{ }^{\circ} \mathrm{C}$ after hardening off, with the ability to keep the frost resistance at $-25^{\circ} \mathrm{C}$ after thaw and ability to restore the hardy state by lowering the temperature to $-30{ }^{\circ} \mathrm{C}$ after thaw and re-hardening off. Cultivars 'Sandra', 'Samo' and 'Make' are recommended for creating new hardy cultivars with high-quality fruits for the temperate continental climate of Europe.
\end{abstract}

Key words: fruit quality, modeling damaging factors, productivity, Venturia inaequalis, winter hardiness

\section{Introduction}

The effectiveness of horticulture in a temperate continental climate depends largely on abiotic environmental factors (Chen et al. 2014), including early frosts, low critical temperatures, thaws, spring frosts, and a short and unstable growing season. Successful horticulture requires hardy, disease-resistant cultivars with high fruit quality, mainly with long-term consumption (Khanizadeh et al. 2000, Onishchenko and Belous 2019). To ensure that high productivity and high quality of fruits do not depend on the whims of nature, it is necessary to ensure that the cultivar combines all the necessary signs of adaptation at the maximum level (Kozlovskaya 2015). The effectiveness of breeding work is largely determined by the presence and correct selection of cultivars with a high level of valuable traits and transmitting these traits to offspring (Kalinina and Makarenko 2013). Currently, the problems of conservation and rational use of plant genetic collections are of strategic importance for each country and remain one of the most important areas of science (Dzyubenko 2015). The experience of modern breeders shows high efficiency of correct assessment and selection of donors of economically valuable traits (Savelyeva 2016).

The All Russian Research Institute of Fruit Crop Breeding began to collect the genetic collection at the end of the 19th century, when a collection of cuttings and apple trees were brought to Russia from North America, which was later supplemented by Central Russian, Western European, and new domestic and foreign cultivars. The preserved apple gene pool is the main resource for creating new cultivars and improving the assortment, it is constantly updated with new accessions from domestic and foreign scientific institutions, including the Baltic countries and Finland.

Finnish cultivars bred to survive in harsh winter conditions were imported to the Institute in 2008. These cultivars were created on the basis of frost-resistance of 'Huvitus', 'Antonovka', 'Kaneli' and 'Atlas' which were crossed with cultivars with high taste qualities - 'Melba', 'Lobo' and 'Yellow Autumn Callville'. Unfavorable northern conditions, i. e. early frosts, long periods of low temperatures and cool summers, create a risk and limit the industrial cultivation of apple trees in South-Western Finland. Severe cold winters, when the air temperature in the southern part of the country falls below $-30^{\circ} \mathrm{C}$, and in Lapland below $-50{ }^{\circ} \mathrm{C}$, occur on average once every 10 years. Finland had exceptionally harsh winters for perennials in 1928/29, 1955/56, 1986/87, 2005/06 (Kaukovirta and Syri 1985). Climate and high cost of cultivation complicate and limit apple production in Northern Europe (Lehtonen 2015). For cultivation of apple trees in Northern conditions, it is necessary to choose cultivars that combine hardiness and high quality of fruit (Linden 2002, Sedov 2011, Seppä et al. 2015).

Orel region being in the central fruit-growing area of Russia is characterized by periodically recurring severe winters with low temperature, spring frosts, a short growing season, and a lack of heat in summer. The average temperature of the winter months is $-8{ }^{\circ} \mathrm{C}$, the absolute minimum temperature is $-39.4{ }^{\circ} \mathrm{C}(2011 / 2012)$. 


\section{AGRICULTURAL AND FOOD SCIENCE}

N. Krasova et al. (2020) 29: 515-525

The growing season is $175-185$ days, the period of active vegetation with a temperature above $10^{\circ} \mathrm{C}$ is $139-149$ days. The Orel region is located in the Central Russian Upland at an altitude of $203 \mathrm{~m}$ above the sea level with moderate continental climate. The experimental station is located Central within the Russian Upland $\left(53^{\circ} 00^{\prime} \mathrm{N}, 36^{\circ} 00^{\prime} \mathrm{E}\right)$. The long-term average annual air temperature is $4.6^{\circ} \mathrm{C}$, in winter periods $-8^{\circ} \mathrm{C}$, in vegetation periods $15.4{ }^{\circ} \mathrm{C}$. In the Orel region, air temperature of $-36^{\circ} \mathrm{C}$ is possible (Strashnyi 1972). The sum of positive temperatures above 10 ${ }^{\circ} \mathrm{C}$ is $2250^{\circ} \mathrm{C}$, the growing season lasts $175-185$ days. The average annual precipitation is $550 \mathrm{~mm}$, and the spring months are often droughty, with dry winds.

Modern market, in order to get high profits, needs cultivars which are both early- and annually fruiting and possess high fruit quality and resistance to diseases and pests. The cultivars that can combine production capabilities with resistance to abiotic factors are particularly valuable. That is why Finnish cultivars that were developed on the basis of local winter-hardy cultivars can be a precious material for further use in breeding when creating adaptive cultivars with high fruit quality. In this regard, the purpose of this work is to study the main production and biological features of Finnish cultivars in the conditions of the Central Russia and to identify winter-hardy cultivars for breeding.

\section{Material and methods}

During the research period (2008-2018), a significant warming was observed in the specified fruit growing zones of Russia in comparison with the average annual indicator, the average temperature of the winter months was $-6.4^{\circ} \mathrm{C}$ with the average long-term temperature $-8.0^{\circ} \mathrm{C}$. Only 2 of 10 winters had temperatures slightly below normal (by $0.6-1.8^{\circ} \mathrm{C}$ ), while the rest of the winters were warmer (up to $1.2-3.7^{\circ} \mathrm{C}$ ) (Table 1 ).

Table 1. Meteorological conditions of the winter period from 2008 to 2018 (December-February) (Data from the VNIISPK weather station)

\begin{tabular}{|c|c|c|c|c|c|c|c|}
\hline Years & $\begin{array}{c}\text { Sum of } \\
\text { average daily } \\
\text { negative } \\
\text { temperatures } \\
\text { (December- } \\
\text { February), } \\
{ }^{\circ} \mathrm{C}\end{array}$ & $\begin{array}{c}\text { Minimal air } \\
\text { temperature, } \\
{ }^{\circ} \mathrm{C}\end{array}$ & $\begin{array}{c}\text { Average air } \\
\text { temperature of } \\
\text { winter months, } \\
{ }^{\circ} \mathrm{C}\end{array}$ & $\begin{array}{l}\text { Deviation from the } \\
\text { average annual air } \\
\text { temperature } \\
\qquad(+,-)\end{array}$ & $\begin{array}{l}\text { Number } \\
\text { of days } \\
\text { with } \\
\text { thaws }\end{array}$ & $\begin{array}{c}\text { Amount of } \\
\text { precipitation, } \\
\mathrm{mm}\end{array}$ & $\begin{array}{l}\text { Deviation } \\
\text { from the } \\
\text { average } \\
\text { annual } \\
\text { sum of } \\
\text { precipitation } \\
(+,-)\end{array}$ \\
\hline $\begin{array}{l}\text { Average for } \\
\text { many years }\end{array}$ & & -36.0 & -8.0 & - & - & 99.0 & - \\
\hline $2008 / 09$ & 536.4 & -19.5 & -4.9 & +3.1 & 16 & 103.1 & +4.1 \\
\hline $2009 / 10$ & 1033.0 & -32.0 & -9.8 & -1.8 & 23 & 114.3 & +15.1 \\
\hline 2010/11 & 946.0 & -34.2 & -8.6 & -0.6 & 5 & 160.2 & +61.2 \\
\hline $2011 / 12$ & 694.1 & -34.0 & -6.8 & +1.2 & 26 & 135.8 & +36.8 \\
\hline 2012/13 & 951.3 & -31.7 & -6.6 & +1.4 & 35 & 104.0 & +5.0 \\
\hline 2013/14 & 576.1 & -31.0 & -5.9 & +2.1 & 20 & 71.0 & -28.0 \\
\hline 2014/15 & 486.1 & -24.5 & -5.1 & +2.9 & 31 & 64.4 & -34.6 \\
\hline $2015 / 16$ & 499.3 & -29.3 & -4.3 & +3.7 & 61 & 118.6 & +19.6 \\
\hline 2016/17 & 601.5 & -24.0 & -6.6 & +1.4 & 28 & 57.8 & -41.2 \\
\hline $2017 / 18$ & 695.0 & -26.1 & -4.9 & +3.1 & 40 & 70.8 & -28.2 \\
\hline
\end{tabular}

For the summer periods of Orel region, warming and decreasing precipitation are also typical during the growing season. The average temperature of the growing season in 2008-2018 exceeded the long-term average temperature by $1.1{ }^{\circ} \mathrm{C}$ and amounted to $16.5^{\circ} \mathrm{C}$ with a decrease in precipitation by $72 \mathrm{~mm}$ (from 312 to $240 \mathrm{~mm}$ ). The growing seasons in 2010, 2012 and 2015 were particularly hot and very dry in the Orel region, when on certain days the air temperature rose to $35^{\circ} \mathrm{C}$, at the soil surface it rose to $43^{\circ} \mathrm{C}$ with a deficiency of precipitation (Table 2).

Cuttings of 11 apple cultivars (Jaspi, Jättimelba, Konsta, Make, Petter, Pirja, Samo, Sandra, Talvikaneli, Tobias, Vuokko) obtained from MTT Piikkiö, Finland were grafted in 2008 directly to the orchard branches of the winter-hardy trees 3-4-98 with 3 trees designated for each cultivar. Trees were planted according to the scheme $4 \mathrm{~m}$ between rows and $2 \mathrm{~m}$ in a row. The observations were made in the period from grafting to 2018 in accordance 


\section{AGRICULTURAL AND FOOD SCIENCE}

N. Krasova et al. (2020) 29: 515-525

with the methodology of cultivar study (Sedov et al. 1999, Tyurina et al. 1999) in the field and in the laboratory by modeling damaging factors using the environmental test chamber ESPEC PSL-2 (Japan). Artificial freezing allows screening genotypes of orchard crops for frost resistance at a high level (Ozherelieva and Sedov 2017). The determination of the stability potential under controlled conditions were carried out according to the main components of the frost resistance complex:

I component $=$ resistance to early winter frosts $\left(-5^{\circ} \mathrm{C},-10^{\circ} \mathrm{C},-30^{\circ} \mathrm{C}\right)$;

II component $=$ the maximum level of frost resistance when hardening off shoots in January-February in the mode $-5{ }^{\circ} \mathrm{C},-10{ }^{\circ} \mathrm{C},-40{ }^{\circ} \mathrm{C}$;

III component $=$ resistance during thaws $\left(-5^{\circ} \mathrm{C},-10^{\circ} \mathrm{C},+2{ }^{\circ} \mathrm{C},-25^{\circ} \mathrm{C}\right)$;

IV component $=$ ability to restore resistance when re-hardening off after thaws $\left(-5{ }^{\circ} \mathrm{C},-10{ }^{\circ} \mathrm{C},+2{ }^{\circ} \mathrm{C},-5{ }^{\circ} \mathrm{C}\right.$, $\left.-10{ }^{\circ} \mathrm{C},-30^{\circ} \mathrm{C}\right)$

Table 2. Meteorological conditions of the growing period from 2009 to 2018 (May-September) (Data from the VNIISPK weather station)

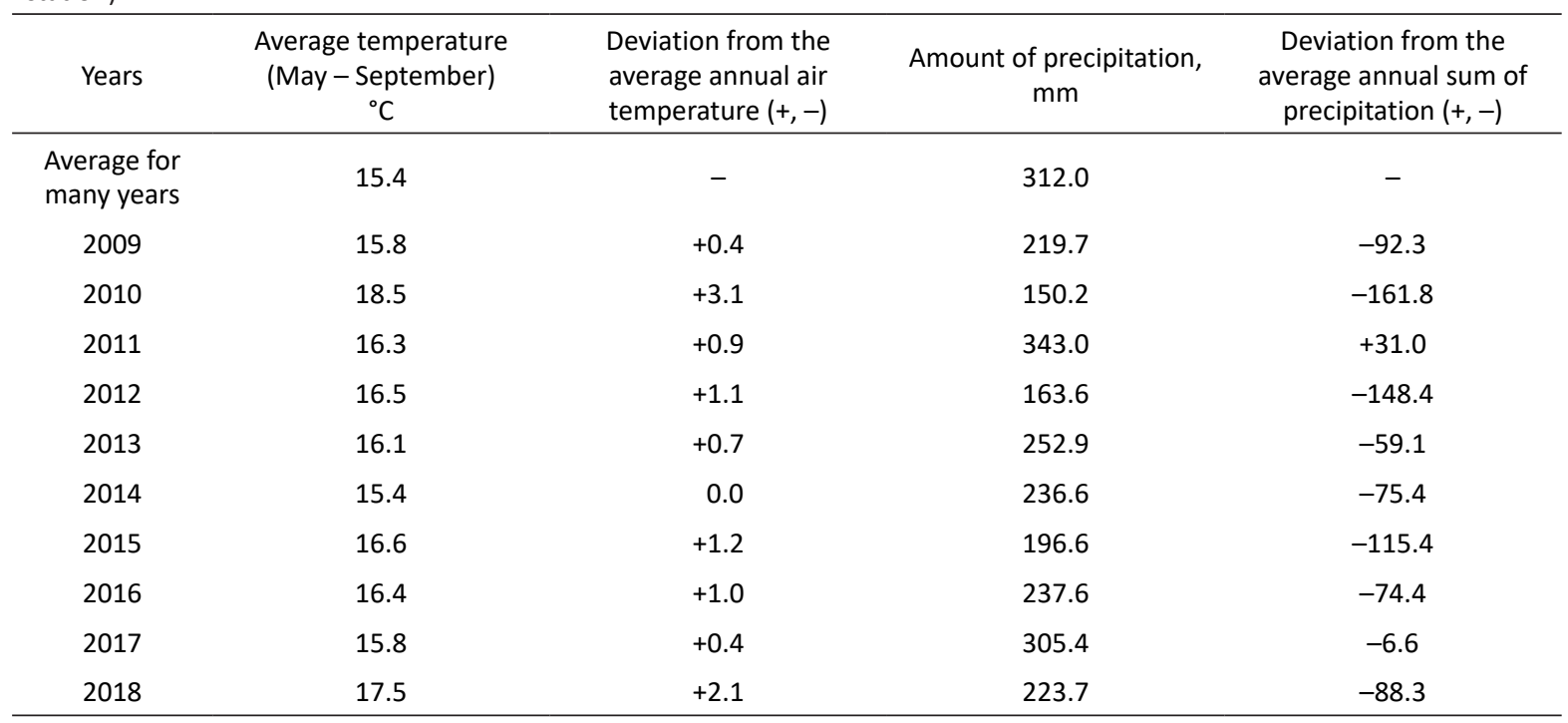

Annual shoots ( 20 shoots of each cultivar) with a standard length $(40-50 \mathrm{~cm}$ ) were taken for freezing at the end of November. Five shoots of each cultivars were studied for four components of frost resistance.

Duration of exposures to temperatures: hardening off $-5{ }^{\circ} \mathrm{C}$ ( 5 days) and $-10^{\circ} \mathrm{C}$ ( 5 days); then reducing the temperature by $5{ }^{\circ} \mathrm{C}$ per hour to the critical temperature. Exposure to freezing -8 hours; thaw $+2{ }^{\circ} \mathrm{C}$ ( 3 days). Evaluation of damage to the buds and browning of shoot tissues was performed using a binocular microscope LZOS MBS-2 (Russia) on a scale from 0 to 5 points: 0 - no damage, 5 - death of tissues and buds after growing back.

Damage to plant tissue and organs in the field during winter were evaluated with points awarded 0-5, where 0 no signs of freezing; 1 - very weak freezing, i.e. the wood was slightly yellowish, small surface burns of the bark were on the trunk and skeletal branches; 2 - weak freezing: light brown wood, weak surface burns of the bark and drying of annual shoots; 3 -significant freezing: brown wood, significant damage to the bark with deadening of bark to wood, death of individual branches; 4 - very strong freezing: dark brown wood, severe bark burns, most of the crown was frozen; 5 - complete freezing of the tree.

Apple tree damage by scab (Venturia inaequalis [Cooke]) was assessed in the field against the background of natural infection, in favorable years for the development of the disease. To assess the degree of scab damage to fruits and leaves, a quantitative scale was used in points, reflecting the number of affected leaves and fruits, the degree of damage, and the intensity of fungal sporulation: 0 - no visible damage; 1 - very weak isolated spots on leaves, small spots in the form of points on fruits; 2 - up to $10 \%$ of the leaves had a few small spots, mediumsized spots were on the fruit, sporulation was slight or moderate; 3 - up to $25 \%$ of the leaf surface was damaged, the fruits had small and large scab spots, sporulation was moderate; 4 - severe leaf damage up to $50 \%$, the spots were large, with dark abundant sporulation, numerous large spots with cracks were on the fruits; 5 - very strong infestation: more than $50 \%$ leaves had large spots, numerous merging, spots with dark sporulation were on fruits. 
Based on the examination of 3 trees ( 25 leaves on each side of the tree), the average score of leaf damage was determined. To account for scab damage during harvesting, a sample of 100 fruits from different trees was taken. The study program included the following fruit qualities: size, appearance assessment, one-dimensionality, pulp assessment by consistency, taste, aroma, and fruit storage duration according to generally accepted methods of cultivar testing (Sedov et al. 1999).

Grouping of apple cultivars by fruit size (average fruit weight) was carried out according to the following gradation (taking into account the international methodology UPOV $\mathrm{Tg} / 14 / 5$ ):

small $=41-70 \mathrm{~g}$

below average $=71-110 \mathrm{~g}$

average $=111-150 \mathrm{~g}$

above average $=151-200 \mathrm{~g}$

large $=201-250 \mathrm{~g}$

The appearance and taste of the fruit were evaluated on a 5-point scale and carried out at the time of optimal fruit maturity by a tasting Committee consisting of 7 people. Attractiveness of fruit appearance was evaluated in points on a scale: 5 - fruits are large, with regular shape and beautiful main and cover color; 4 - medium-sized attractive fruits; 3 - fruits of a mediocre type, below average size, not very attractive; 2 - small fruits, unsuitable in color and shape; 1 - fruits are very ugly and very small.

The taste of the fruit was evaluated in points: 5 - excellent dessert taste; 4 -good table taste; 3 - mediocre taste; 2 - not suitable for consumption, 1 - not edible. When determining the average score when summarizing data from a number of tasters, tenths of the score were added to the whole points.

The structure of the fruit pulp can be coarse-grained, fine-grained, dense, crisp, tender, meaty, juicy, medium-juicy or dry. The onset of removable maturity was noted at the time where the fruits reached normal size and the corresponding color, by the ease of separating the fruits and by seed browning. The fruits were stored in a refrigerator at a temperature of $0-5{ }^{\circ} \mathrm{C}$ and humidity of $85-90 \%$. The duration of storage of fruits was determined from the moment of harvest to rejection of $10-15 \%$ of fruits.

All results were tested by one-way analysis of variance ANOVA (Version 22, SPSS).

\section{Results}

During the period of cultivar study, the conditions were generally favorable for good growth and development of trees. During the first 7-8 years, the trees of the studied cultivars successfully suffered a temperature drop to $-34.5^{\circ} \mathrm{C}$ on the snow surface (without thawing). After the winter of $2014 / 2015$, apple trees were examined in the field. In the autumn 2014 the trees were well tempered with a gradual transition to low temperatures in November-December (in October 2014 average air temperature was $2.8^{\circ} \mathrm{C}$, in November $-2.2^{\circ} \mathrm{C}$, and in December $-5.1^{\circ} \mathrm{C}$ ). The average temperature of the winter months was $2.9^{\circ} \mathrm{C}$ higher than the average temperature for many years; the minimum temperature did not fall below $-24.5^{\circ} \mathrm{C}$. That winter, reversible damage to wood at the level of Melba standard (2.0 points) was revealed in 'Jättimelba', 'Konsta', 'Petteri' and 'Tobias'. Weak damage (1.0-1.1 points) was in 'Jaspi', 'Make', 'Pirja', 'Sandra', 'Samo', 'Talvikaneli' and 'Vuokko' at the level of 'Antonovka'. The bark and cambium were undamaged in the field.

The subsequent winters between 2016 and 2018 were unstable, mild, with frequent thaws and temperature fluctuations. The winters of 2015/16 and 2017/2018 were particularly unfavorable, with a large number of days with thaws. So, in the winter of $2017 / 2018$ after a warmer December (average air temperature $0.6{ }^{\circ} \mathrm{C}$ ) and January $\left(-4.9^{\circ} \mathrm{C}\right.$ ) with an average long-term $-5.6^{\circ} \mathrm{C}$ and $-9.7^{\circ} \mathrm{C}$ (respectively), a sharp drop in temperature followed in February and March. Unstable conditions with temperature fluctuations in February and March from $+2{ }^{\circ} \mathrm{C}$ to $-26.0^{\circ} \mathrm{C}$ temperatures contributed to the reduction of winter hardiness of Finnish apple cultivars.

To find out the reaction of apple cultivars to various factors of the winter period (including thaw) and establish the threshold of stability, the research program included the determination of the resistance of cultivars to climate stresses by modeling damaging factors. Modeling of $-40^{\circ} \mathrm{C}$ frost after hardening off contributed to bud damage in all cultivars at the level of 'Melba' standard, but stronger than in 'Antonovka'. Damage to the bark of 


\section{AGRICULTURAL AND FOOD SCIENCE}

N. Krasova et al. (2020) 29: 515-525

shoots when exposed to this temperature was also stronger than damage to 'Antonovka' (Table 3). At the 'Melba' level, reversible damage to the bark was observed in the 'Make', 'Sandra', and 'Samo' (1.3-2.3 points), the other cultivars significantly exceeded the damage of the bark in 'Melba' and 'Antonovka'. 'Make', 'Samo' and 'Sandra' showed stability of vital tissues of cambium and wood at the level of 'Antonovka' (1-1.5 points). Significant damage to the cambium ( 3.2 points) and bark ( 3.3 points) was noted in 'Vuokko'. The damage in the other cultivars was comparable to the level of 'Melba'.

Table 3. Damage to apple cultivars during artificial freezing of shoots according to the components of frost resistance in winter 2019/2020

\begin{tabular}{|c|c|c|c|c|c|c|c|c|}
\hline \multirow{3}{*}{ Cultivars } & \multicolumn{8}{|c|}{ Damage, points } \\
\hline & \multicolumn{4}{|c|}{ Component II $\left(-5^{\circ} \mathrm{C},-10^{\circ} \mathrm{C},-40^{\circ} \mathrm{C}\right)$} & \multicolumn{4}{|c|}{ Component III $\left(-5^{\circ} \mathrm{C},-10^{\circ} \mathrm{C},+2{ }^{\circ} \mathrm{C},-25^{\circ} \mathrm{C}\right)$} \\
\hline & buds & bark & cambium & wood & buds & bark & cambium & wood \\
\hline Melba & $3.2 \mathrm{a}$ & $1.5 b$ & $1.2 b$ & 1.0 & $1.8 \mathrm{a}$ & $0.8 a$ & $0.3 b$ & - \\
\hline Antonovka & $1.3 \mathrm{c}$ & $0.1 c$ & $0.1 \mathrm{c}$ & 0.9 & $0.3 c$ & $0.2 b$ & $0.2 b$ & 0.0 \\
\hline Konsta & 4.0a & $2.5 a$ & $1.7 \mathrm{~b}$ & 1.5 & $2.0 a$ & $1.2 \mathrm{a}$ & $0.7 a$ & 0.0 \\
\hline Make & 3.0a & $1.7 b$ & $1.0 \mathrm{~b}$ & 1.2 & $1,5 a$ & $0.8 a$ & $0.3 b$ & 0.0 \\
\hline Petteri & $3.8 a$ & $2.8 a$ & $2.3 a$ & 2.0 & $1.7 a$ & $1.0 a$ & $0.3 b$ & 0.0 \\
\hline Pirja & $3.7 a$ & $2.5 a$ & $2.5 a$ & 1.0 & $0.8 \mathrm{~b}$ & $0.5 a$ & $0.0 \mathrm{~b}$ & 0.0 \\
\hline Samo & $3.7 a$ & $2.3 b$ & $1.5 b$ & 0.5 & $1.0 \mathrm{~b}$ & $0.2 b$ & $0.0 \mathrm{~b}$ & 0.0 \\
\hline Sandra & $2.7 a$ & $1.3 b$ & $1.0 \mathrm{~b}$ & 1.0 & $1.0 \mathrm{~b}$ & $0.3 b$ & $0.0 \mathrm{~b}$ & 0.0 \\
\hline Tobias & $3.5 a$ & $3.0 a$ & $2.5 a$ & 0.5 & $1.2 b$ & $0.5 a$ & $0.2 b$ & 0.0 \\
\hline Vuokko & $3.8 a$ & $3.3 a$ & $3.2 a$ & 1.5 & $0.7 b$ & $0.3 b$ & $0.0 \mathrm{~b}$ & 0.0 \\
\hline
\end{tabular}

different letters in the same column indicate differences in the damage of cultivars

In terms of wood stability, the studied cultivars did not differ significantly from the controlled cultivars. 'Make', 'Samo' and 'Sandra' were identified as the most stable cultivars (Fig. 1), the tissues of which had small reversible damage.

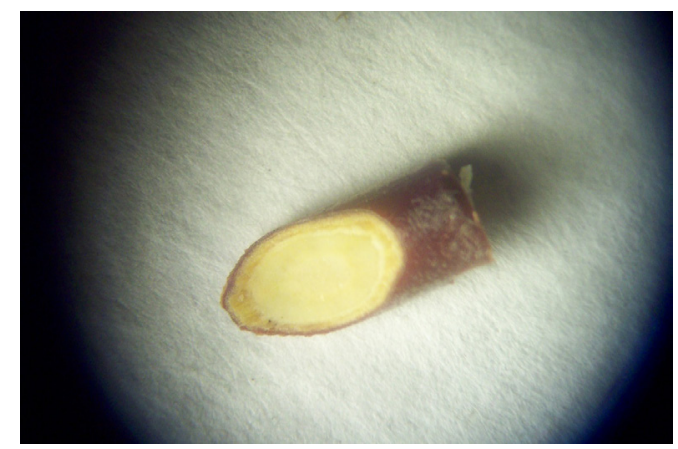

Fig. 1. Low tissue damage seen as a slight darkening in annual branch of 'Sandra' at $-40{ }^{\circ} \mathrm{C}$ (damage points: bark -

1.3, cambium - 1.0, wood - 1.0) (II Component)

Long-term observations of the condition of fruit trees in the Russian central zone have shown that winter damage to the tissues and buds of apple trees can occur as a result of severe frosts, and in mild winters it could be from frosts after thaws and sharp daily fluctuations in air temperature. Therefore, the stability of a fruit tree to frosts after thaw is essential in winter and early spring. Modeling of $-25^{\circ} \mathrm{C}$ frost after a three-day thaw of $2{ }^{\circ} \mathrm{C}$ showed a different reaction of cultivars to thaw. Vegetative buds and bark of 'Melba' were damaged more than in 'Antonovka', while cambium damage in these cultivars did not differ significantly.

The buds and tissues of 'Pirja', 'Sandra', 'Samo', and 'Vuokko' were resistant to frost after thaw (with damage significantly less than in 'Melba' and at the level of 'Antonovka') (Fig. 2). 
For the stability of cambium the studied apple cultivars were at the level of 'Antonovka' and 'Melba', except for the 'Konsta' with damage to cambium significantly higher than in the standard cultivar when exposed to temperatures of $-25^{\circ} \mathrm{C}$ after a thaw at $+2{ }^{\circ} \mathrm{C}$. No damage to wood was observed in this mode of freezing (Table 3 ).

a)

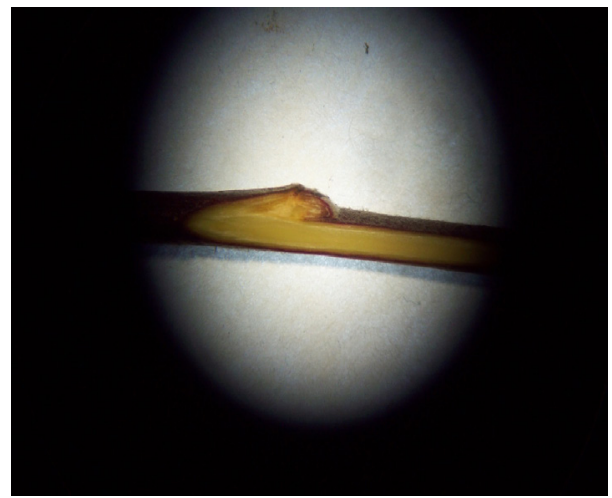

b)

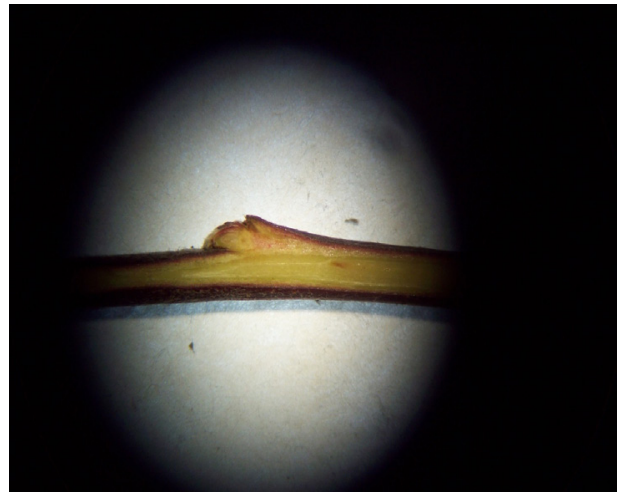

Fig. 2. Damage to vegetative buds and tissues of annual branches of Melba (a) and Vuokko (b) at $-25^{\circ} \mathrm{C}$ after a three-day thaw at $+2{ }^{\circ} \mathrm{C}$. Visible damage in both: 'Melba' (damage points: buds - 1.8 , bark - 0.8 , cambium 0.3 ) and 'Vuokko' (damage points: buds - 0.7, bark - 0.3, cambium - 0.0, wood - 0.0) (III Component)

The ability not only to maintain frost resistance during thaws, but also to restore it after frosts is important. 'Melba' did not differ significantly from 'Antonovka' in the ability to restore tissue stability at $-30{ }^{\circ} \mathrm{C}$ after a three-day thaw at $+2{ }^{\circ} \mathrm{C}$ and hardening off. At this level (not more than 1.0 point), there was tissue damage in the studied cultivars. The ability to restore the frost resistance of the buds when hardening off after thawing at a simulated frost of $-30{ }^{\circ} \mathrm{C}$ (frost resistance component IV) was found in all cultivars at the level of 'Melba', while in 'Pirja', 'Sandra' and 'Vuokko' (Fig. 3) it was higher than in 'Melba' and was at the level of 'Antonovka'.

a)

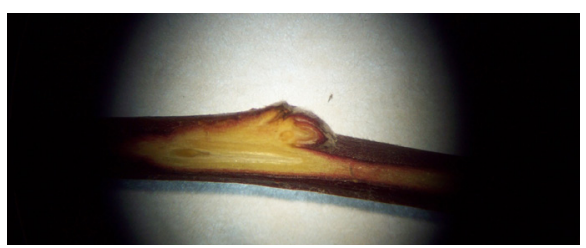

b)

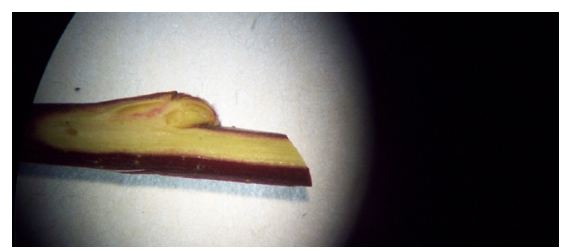

Fig. 3. Damage to vegetative buds and tissues of annual branches of Melba (a) and Vuokko (b) at $-30^{\circ} \mathrm{C}$ after a three-day thaw at $+2{ }^{\circ} \mathrm{C}$ and re-hardening off. 'Melba' (damage points: buds -1.5 , bark - 0.1 , cambium 0.1, wood - 1.7); 'Vuokko' (damage points: buds - 0.5, bark - 0.1, cambium - 0.1, wood - 0,4) (IV Component)

\section{Productivity, quality and scab resistance of the cultivars}

The results of the yield and quality of fruits of the studied cultivars are presented in Table 4.

Productivity and consumer qualities of fruits are largely determined by the genotype of the cultivar, as well as the growing conditions. 'Jaspi', 'Jättimelba' and 'Petteri' bloomed and gave the first fruit in the second year after grafting; the most rapid-growing 'Vuokko' at this age recorded a yield of more than $5 \mathrm{~kg}$ per tree. The other cultivars bloomed in the third or fourth year after grafting. The amount of the yield was largely affected by adverse conditions during flowering in some years. So, in mid-May 2017, during apple blossom, the air temperature dropped to $-2{ }^{\circ} \mathrm{C}$ and on the soil surface to $-3.7^{\circ} \mathrm{C}$ with a cold strong north and north-east wind. In such extreme conditions, with good flowering, damage to the pistils in the flowers was noted, which negatively affected the yield in most apple cultivars. Under favorable conditions, the yield of 'Tobias', 'Jättimelba', 'Make' and 'Vuokko' was 20-30 kg per tree (25-38 t ha-1).

On average, during 2015-2018, the cultivars of Finnish selection showed moderate yields at the level of 'Melba' and 'Antonovka'. 'Vuokko' stood out from this group with an average yield significantly higher than 'Antonovka' and 'Melba' (Table 4).

The date of maturation and the consumption duration of fruit are significantly determined by the origin of the cultivars. Fruits of 'Pirja', 'Vuokko', 'Jättimelba' and 'Samo', in the origin of which 'Melba' and 'Huvitus' have participated, ripened in summer (early-mid-August). In the central zone of fruit-growing in Russia, the earliest fruit 
maturation was observed in 'Pirja' - in the last 10 days of July. The fruit maturation was observed in the autumn in those cultivars that were derived from the winter 'Lobo' cultivar. A longer period of storage for fruits was observed in 'Konsta' ('Lobo' × 'Antonovka') - until late November - early December.

Table 4. Productivity, scab damage and fruit quality of apple cultivars (2015-2018)

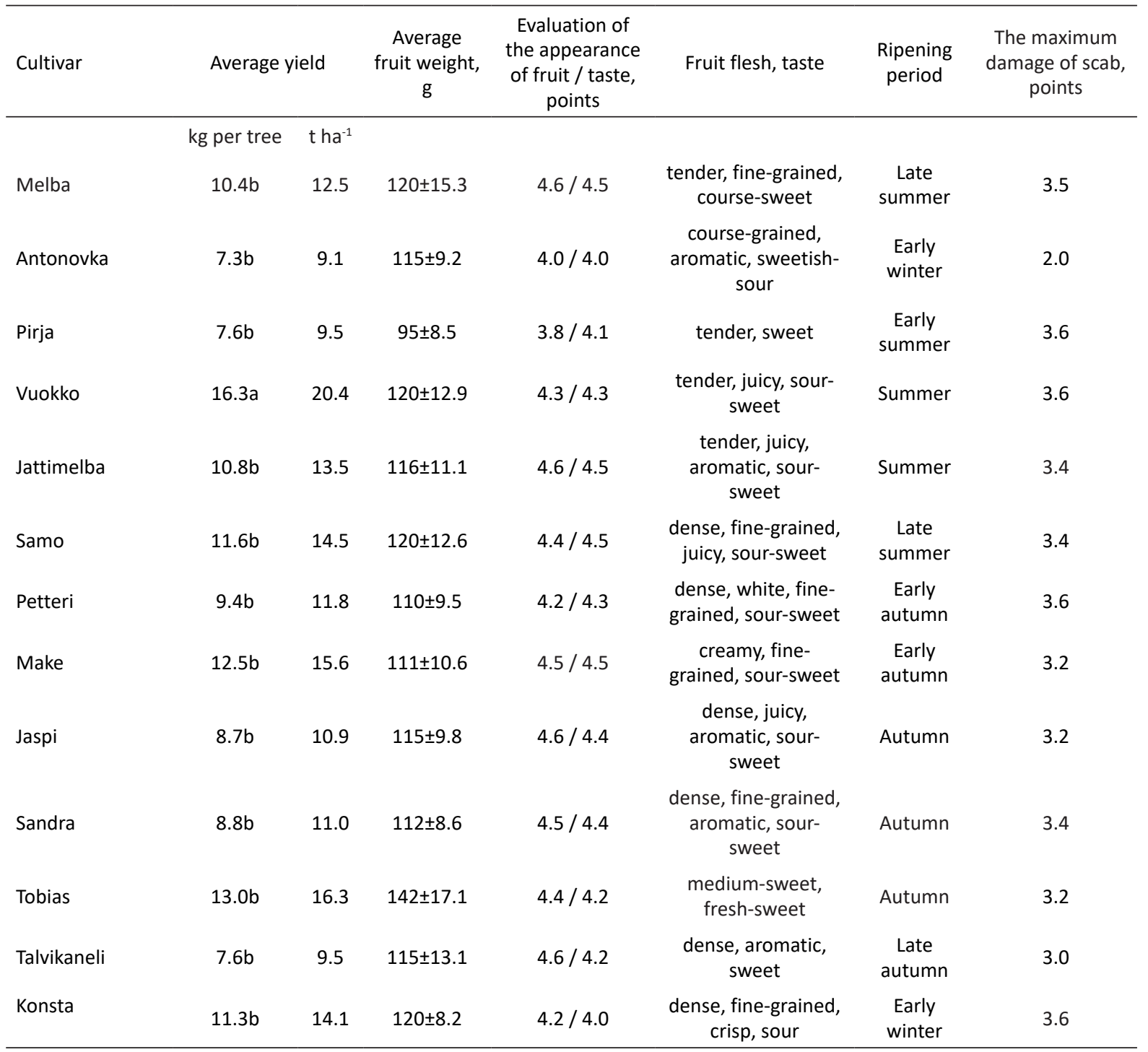

different letters in the same column indicate differences in the yield of cultivars

'Pirja' was identified as an early-summer cultivar with fruit maturation earlier than in other cultivars at the end of July. The fruits of this cultivar are below average size (95 g), nondescript in appearance, with weak ribbing and blurred red stripes, sweet and aromatic.

The 'Vuokko' fruits are medium-sized (120 g), oval-conical, with a red blurred blush, good sweet and sour taste. The fruits of 'Jättimelba' are rounded and conical, with a dark red blush, thin skin. The flesh is white tender and aromatic.

The fruits of 'Samo' are medium-sized (120 g), round-conical, the cover color is dark red blurred, the flesh is dense and fine-grained, with a pleasant sweet and sour taste. The fruits of 'Make' are rounded-conical, slightly ribbed, with a pleasant sweet and sour taste. The fruits of the rapid-fruiting 'Petteri' are one-dimensional, flat-rounded, the skin is thin, with a bluish coating. The flesh is dense, white, and sometimes with red veins. The taste is harmonious, sweet and sour.

Autumn ripening 'Sandra' gives round-conical fruits of medium size, the skin is thin, the cover color is beautifuldark red striped that merge into a thick blurred blush over the entire surface of the fruit. The taste is harmonious sweet and sour. 


\section{AGRICULTURAL AND FOOD SCIENCE}

N. Krasova et al. (2020) 29: 515-525

The fruits of 'Tobias' are oval-conical, with a dense skin covered with a solid blurry-striped blush. The flesh is pale cream, sometimes with red streaks, the taste is bland and sweet. The fruits of 'Talvikaneli' are medium-sized, round-conical, with a slight ribbing, with a beautiful red blurred blush, taste with a predominance of sweetness, with a cinnamon flavor. Early winter 'Konsta' produces rounded-conical fruits, with a dark red, dull, blurred blush. The flesh is white, dense, crisp and sour.

The color of all cultivars studied was more pronounced in conditions of sharp fluctuations in air temperature in the daytime and at night during the ripening period. That was observed in 2015, 2016 and 2018, when the difference in day and night temperatures in August was $20-24^{\circ} \mathrm{C}$.

During 2009 to 2018 the studied Finnish cultivars showed insufficient resistance to scab (Venturia inaegualis [Cook]) which causes great harm to apple orchards. The fruits and leaves of 'Konsta', 'Vuokko', 'Pirja' and 'Petteri' were most affected by scab (3.6 points) at the level of 'Melba', but stronger than 'Antonovka'.

\section{Discussion}

The Central zone of fruit-growing in Russia is very similar to the conditions in the South-Western part of Finland, where commercial gardening is possible. A short growing season and insufficient summer heat combined with unfavorable winter conditions are the main indicators that limit the cultivation of high-quality apple cultivars in the south-west of Finland and in the central zone of Russia (Kaukoranta et al. 2010, Krasova et al. 2013). According to Seppä et al. 2016 during the growing season the average air temperature for many years in Helsinki is 13.8 ${ }^{\circ} \mathrm{C}$, while in the Orel region it is $15.4{ }^{\circ} \mathrm{C}$ (by $1.6^{\circ} \mathrm{C}$ more) the amount of precipitation for this period is 309 and 312 $\mathrm{mm}$, respectively.

In the field during the past winters with frosts to $-34^{\circ} \mathrm{C}$ with good hardening off in the autumn period, the stability of tissues at the level of the winter-hardy cultivar 'Antonovka' was revealed in 'Jaspi', 'Make', 'Pirja', 'Samo', 'Sandra', 'Talvikaneli' and 'Vuokko'. The stability of 'Jättimelba', 'Konsta', 'Petteri' and 'Tobias' did not exceed the level of moderately hardy 'Melba'. The bark and cambium were undamaged in the field.

The study of the reaction of the cultivars to lower temperatures by modeling frost $-40{ }^{\circ} \mathrm{C}$ showed some differences in the stability of tissues and buds of the studied Finnish cultivars. At the 'Melba' level, reversible damage to the bark was observed in 'Make', 'Sandra' and 'Samo' while the other cultivars significantly exceeded the damage to bark in the standard cultivar.

'Make', 'Samo' and 'Sandra' showed stability of vital tissues, i. e. cambium and wood at the level of 'Antonovka' (the damage was not more than 1-1.5 points). The significant damage to the cambium (3.2 points) and bark (3.3 points) was noted in 'Vuokko'. The damage in the other cultivars was at the level of 'Melba'. In terms of wood stability, the studied cultivars did not differ significantly from the control.

For further use the most stable cultivars 'Make', 'Samo' and 'Sandra' were selected. Their cambium and wood withstood the modeled temperature $-40^{\circ} \mathrm{C}$ after hardening off with small reversible damage at the level of 'Antonovka'. In an unstable climate, the ability of the cultivars to keep stability in winter after thaws is important (Krasova 2014).

Frost modeling of $-25^{\circ} \mathrm{C}$ after a three-day thaw at $2{ }^{\circ} \mathrm{C}$ allowed identification of reactions of cultivars to thaw. The previous conclusion that Finnish cultivars did not have the ability to maintain stability during thaws (Linden et al. 1999) was confirmed only partially and largely depended on the duration of the thaw and the severity of the frost. After thaw, buds and bark in 'Melba' and 'Konsta' were more damaged than in 'Antonovka'.

Under the specified freezing conditions in our experiments, 'Pirja', 'Sandra', 'Samo' and 'Vuokko' showed high resistance of buds and tissues to frost after thaw at the level of 'Antonovka' with damage to the buds no more than 1.0 point, to bark no more than 0.5 point, cambium and wood were completely without damage. Thaw with the subsequent impact of $-25{ }^{\circ} \mathrm{C}$ had the strongest influence on 'Konsta'. Except for this cultivar, all other cultivars showed high resistance of cambium to frosts after thaws. When modeling freezing of $-30{ }^{\circ} \mathrm{C}$ after a three-day thaw at $+2{ }^{\circ} \mathrm{C}$ and re-hardening off, the ability to restore frost resistance at the 'Melba' level was determined in most cultivars, except for 'Konsta' and 'Petteri'. 


\section{AGRICULTURAL AND FOOD SCIENCE}

N. Krasova et al. (2020) 29: 515-525

As a result of modeling damage factors of the winter period, the cultivars 'Sandra', 'Samo' and 'Make' in the field showed resistance at the level of 'Antonovka', and they could withstand the temperature of $-40{ }^{\circ} \mathrm{C}$ at the level of 'Antonovka' when freezing after hardening off with little damage to the cambium to 1.5 points and reversible damage of the bark to 2.3 points ('Samo'). These cultivars showed a high ability to maintain stability in frosts up to $-25^{\circ} \mathrm{C}$ after a three-day thaw at $+2{ }^{\circ} \mathrm{C}$, as well as lowering the temperature to $-30{ }^{\circ} \mathrm{C}$ after a three-day thaw $+2{ }^{\circ} \mathrm{C}$ and re-hardening off. 'Vuokko' showed resistance to frost after thaw at the level of 'Antonovka', but it was worse than others when simulating a drop in temperature to $-40^{\circ} \mathrm{C}$.

'Samo', according to Linden et al. 1999, with controlled freezing in mid-March, also showed a high stable level of resistance, but it was still slightly below the level of 'Antonovka', as well as in our conditions. The other cultivars showed resistance according to the components of frost hardiness at the level of 'Melba'.

Stability of frost hardiness and the degree of influence of re-hardening off are the main factors for selecting cultivars for growing in the conditions of unstable winters (Tyurina et al. 1999). Rootstocks, location of cultivation and cultivation technology play an important role in the formation of winter hardiness and productivity (Hampson et al. 2004, Thybo et al. 2005, Seppä et al. 2013, Kviklys et al. 2016). Grafting of Finnish apple cultivars into the crown of a hardy skeletal tree allowed to identify the most stable and productive cultivars and preserve all grafted cultivars completely. On average, during the years of the study (2015-2018) 'Vuokko', 'Jättimelba', 'Samo', 'Make', 'Tobias' and 'Konsta' that were grafted into the crown of a hardy skeletal tree, showed yields at the level of 'Melba'. 'Vuokko' stood out from this group, with an average yield of $16.3 \mathrm{~kg}$ per tree $\left(20.4 \mathrm{t} \mathrm{ha}^{-1}\right)$, that is higher than all other cultivars.

Our observations during the ripening of the studied cultivars mostly coincides with the data of the Finnish authors (Tahvonen 2007). Summer and autumn cultivars ripened a few days earlier in dry and hot years. 'Pirja' was noted as an early-summer cultivar and its fruit ripened earlier than others, at the end of July. The fruits of 'Vuokko', 'Samo' and 'Jättimelba' ripened a little earlier than 'Melba' and were stored for 2-3 weeks. The fruits of 'Make' and 'Petteri' ripened at the 'Melba' level in late August and early September, and were stored until mid-October (4-5 weeks). Fruits harvesting period of 'Sandra', 'Jaspi', 'Tobias', 'Talvikaneli' and 'Konsta' was in mid-September, the fruits of 'Sandra', 'Jaspi', 'Tobias' were stored for 6-7 weeks, and 'Talvikaneli' for 8 weeks. 'Konsta' had the longest period of fruit storage - until the end of December.

According to the fruit size, the studied cultivars were classified as average-sized (101-150 g). Climate change has a significant impact on fruit quality (Suguira et al. 2013). The fruits of 'Tobias' were not one-dimensional by years with fluctuations in fruit weight from 110 to $160 \mathrm{~g}$ depending on the conditions of the year; in warm years, the fruits were larger, with a beautiful intense color, more juicy and delicious, with flavor. Lower than average in size were the fruits of 'Pirja', the cultivar of early-summer maturation. Under the conditions of dry and hot July 2012 and 2014, there was a strong shedding of fruits of this cultivar. The fruits of 'Jättimelba' were very similar to 'Melba' in the character and stability of taste, but the cover color was more blurred and the fruits overriped faster. The assessment and stability of the taste and color intensity of fruits was largely determined by the weather conditions of the year. 'Petteri' had a consistently sweet fruit taste, while 'Samo', 'Make' and 'Vuokko' have a good sweet and sour taste. Seppä et al. (2016) reported about a consistent taste of late-ripening fruits under various annual climatic conditions. For ex. 'Konsta', the winter cultivar, has a constant acidic taste.

\section{Conclusion}

In the temperate continental climate of Russia a number of Finnish apple cultivars showed good adaptive potential to adverse environmental conditions both in the field and laboratory. In the field, the Finnish cultivars showed hardiness at the level of Antonovka.

As a result of modeling damaging factors by components of frost resistance in winter, the most winter-hardy cultivars were identified. 'Sandra', 'Samo' and 'Make' survived the critical temperature of $-40{ }^{\circ} \mathrm{C}$ with minimal damage to the cambium and wood at the level of 'Antonovka'. Damage to the buds and bark in these cultivars was at the level of' Melba'.

All the studied cultivars, except 'Konsta', showed good resistance to frost after thaws at the level of 'Melba' and 'Antonovka'. 
'Petteri', 'Jättimelba' and 'Jaspi' began to fructify the next year after grafting in the crown of the skeletal tree. 'Make', 'Tobias' and 'Vuokko' gave high yields during 11 years of growing in the orchard (an average of 12-16 kg per tree).

'Petteri' was selected as a cultivar with fruits of a pleasant sweet taste, dense fine-grained and juicy flesh. According to the fruit appearance, consistency of the flesh and taste, 'Jättimelba', 'Samo' and 'Jaspi' were rated at the 'Melba' level.

As a result of a comprehensive assessment of economic and biological indicators, 'Sandra', 'Make' and 'Samo' are recommended for breeding new adaptive apple cultivars with high taste qualities for a temperate continental climate.

\section{References}

Chen, L.-J., Xiang, H.-Z., Miao, Y., Zhang, L., Cuo, Z.-F., Zhao, X.-H., Lin, J.-W. \& Li, T.-L. 2014. An overview of cold resistance in plants. Journal Agronomy and Crop Science 200: 237-245. https://doi.org/10.1111/jac.12082

Dzyubenko, N.I. 2015. Genetic resources of cultural plants is the basis of food and environmental security in Russia. Vestnik Rossiiskoi Akademii Nauk 85: 3-8. (in Russian). https://doi.org/10.1134/S1019331615010013

Hampson, C.R., Quamme, H.A., Kappel, F. \& Brownlee, R.T. 2004. Varying density with constant rectangularity: II. Effects on apple tree yield, fruit size, and fruit color development in three training systems over ten years. HortScience 39: 507-511. https://doi.org/10.21273/HORTSCl.39.3.507

Kalinina, I.P. \& Makarenko, S.A. 2013. Results and prospects of apple breeding in the Altai. Achievements of science and technology in the Altai 7: 9-11. (in Russian).

Kaukoranta, T., Tahvonen, R. \& Ylämäki, A. 2010. Climatic potential and risks for apple growing by 2040. Agricultural and Food Science 19: 144-159. https://doi.org/10.2137/145960610791542352

Kaukovirta, E. \& Syri, P. 1985. An attempt to reanalyze winter injury of apple trees in Finland during this century. Acta Horticulturae 168: 73-83. https://doi.org/10.17660/ActaHortic.1985.168.6

Khanizadeh, S., Grzyb, Y., Cousineau, J., Granger, R. \& Rousselle, G. 2000. New hardy apple selections from the Quebec apple breeding program. Acta Horticulturae 538: Eucarpia symposium on Fruit Breeding and Genetics: 129. https://doi.org/10.17660/ActaHortic.2000.538.129

Kozlovskaya, Z.A. 2015. Apple breeding in Belarus. Minsk. Belarusskaya Nauka. 457 p. (in Russian).

Krasova, N., Galasheva, A. \& Golishkina, L. 2013. Apple-tree resistance to abiotic factors in winter. Proceedings of the Latvian academy of sciences 67: 136-144. https://doi.org/10.2478/prolas-2013-0021

Krasova, N.G., Ozherelieva, Z.E., Golyshkina, L.V., Makarkina, M.A. \& Galasheva, A.M. 2014. Winter hardiness of apple cultivars. Orel: VNIISPK. 183 p. (in Russian).

Kviklys, D., Čeidaitè, A., Lanauskas, J., Uselis, N. \& Samuolienè, G. 2016. The effect of rootstock on apple tree bearing stability in a cooler climate 2016. Agricultural and Food Science 25: 81-88. https://doi.org/10.23986/afsci.53381

Lehtonen, H. 2015. Evaluating adaptation and the production development of Finnish agriculture in climate and global change. Agricultural and Food Science 24: 219-237. https://doi.org/10.23986/afsci.51080

Linden, L. 2002. Measuring cold hardiness in woody plants. University of Helsinki, Department of Applied Biology, Helsinki. Publication 10.

Linden, L., Palonen, P. \& Seppänen, M. 1999. Cold hardiness research on agricultural and horticultural crops in Finland. Agricultural and Food Science in Finland 8: 459-477. https://doi.org/10.23986/afsci.5641

Onischenko, K.V. \& Belous, O.G. 2019. Analysis of the main trends in apple cultivation (literature review). Subtropical and ornamental horticulture 68: 137-146. (in Russian). https://doi.org/10.31360/2225-3068-2019-68-137-146

Ozherelieva, Z.E. \& Sedov, E.N. 2017. Low temperature tolerance of apple cultivars of different ploidy at different times of the winter. Proceeding of the Latvian Academy of Sciences. Section B, 71: 127-131. https://doi.org/10.1515/prolas-2017-0022

Savelyeva, N.N. 2016. Biological and genetic features of apple and breeding of scab immune and columnar cultivars. Scientific publication Michurinsk center. 270 p. (in Russian).

Sedov, E.N. 2011. Breeding and new apple cultivars. Orel: VNIISPK. 621 p. (in Russian).

Sedov, E.N., Krasova, N.G., Zhdanov, V.V., Dolmatov, E.A. \& Mozhar, N.V. 1999. Pome crops (apple, pear, quince). Program and methods of cultivar study of fruit, berry and nut crops. Orel: VNIISPK. p. 253-300. (in Russian).

Seppä, L., Peltoniemi, A., Tahvonen, R. \& Tuorila, H. 2013. Flavor and texture changes in apple cultivars during storage. LWT. Food Science and Technology 54: 500-512. https://doi.org/10.1016/j.Iwt.2013.06.012

Seppä, L., Latvala, T., Akaich, I.F., Gil, J.M. \& Tuorila, H. 2015. What are domestic apples worth? Hedonic responses and sensory information as drivers of willingness to pay. Food Quality and Preference 43: 97-105. https://doi.org/10.1016/j.foodqual.2015.02.013

Seppä, L., Tahvonen, R. \& Tuorila, H. 2016. Annual variation in sensory characteristics of seventeen apple cultivars. Agricultural and Food Science 25: 202-215. https://doi.org/10.23986/afsci.57343

Strashnyi, V. N. 1972. Agro-climatic resources of the Orel and Lipetsk regions. Leningrad. Gidrometioizdat. 118 p. (in Russian). 


\section{AGRICULTURAL AND FOOD SCIENCE}

N. Krasova et al. (2020) 29: 515-525

Suguira, T., Ogawa, H., Fukuda, N. \& Moriguchi, T. 2013. Changes in the taste and textural attributes of apples in response to climate change. Scientific Reports 3: 2418. https://doi.org/10.1038/srep02418

Tahvonen, R. 2007. Apple cultivation. Helsinki: Horticultural Society. 246 p. (in Finnish).

Thybo, A.K, Sørensen, L., Christensen, L.P. \& Kühn, B.F. 2005. Quality of apples grown in a Scandinavian high-density orchard and chemical composition in relation to sensory quality. The Journal of Horticultural Science and Biotechnology 80: 727-735. https://doi.org/10.1080/14620316.2005.11512006

Tyurina, M.M., Krasova, N.G., Rezvyakova, S.V., Savelyev, N.I., Dzhigadlo, E.N. \& Ogoltsova, T.P. 1999. Study of winter hardiness of fruit and berry plants in field and laboratory conditions. Program and the methods of cultivars study of fruit, berry and nut crops. Orel: VNIISPK: 59-69. (in Russian). 